\title{
Editorial: Celebrating the centennial of the RAS Institute of Philosophy
}

\author{
Marina F. Bykova ${ }^{1}$ (]
}

Published online: 3 December 2021

(๑) The Author(s), under exclusive licence to Springer Nature B.V. 2021

The year 2021 marks the 100th anniversary of the inception of the Institute of Philosophy of the Russian Academy of Sciences. The Institute's history goes back to 4 March, 1921, when, by decree of the People's Commissariat for Education of the Russian Soviet Federative Socialist Republic (RSFSR), the Institute of Scientific Philosophy was established (Guseinov and Smirnov 2021, p. 11; Guseinov 2021, p. 505). Organized at the request of the prominent Russian phenomenologist Gustav G. Shpet, who served as its first Director, the Institute of Scientific Philosophy was tasked with the "education of thought" needed for the formation of a new society and culture. While founded as an independent institution with the goal of the development of scientific philosophy, in 1929 the Institute of Scientific Philosophy was integrated into the Communist Academy, and after merging with the Academy's Philosophical Section, was renamed the Institute of Philosophy. Abram M. Deborin, who at that time led both institutional structures-the one founded by Shpet and the Academy's Section - was put at the helm of the newly inaugurated Institute. One of the principal aims of the Institute at its inception was the creation of a comprehensive and definitive Encyclopedia of World Philosophy, a goal that remained unachieved because of Stalin's anti-cosmopolitan campaign and other repressions against the intelligentsia and philosophers in particular (Guseinov 2021, p. 506). In 1936, the Institute of Philosophy came under the auspices of the USSR Academy of Sciences, and since 1991 it has been an essential part of the Russian Academy of Sciences. Several research groups that evolved within the Institute of Philosophy eventually developed into other independent institutions of the Academy of Sciences, such as the Institute of Psychology and the Institute of Sociology.

The 100-year history of the RAS Institute of Philosophy boldly depicts the arduous history of the development of philosophy in Soviet Russia. Thus, the centennial anniversary is a fitting occasion for recalling what the past was like and perhaps overturning some typical clichés. The clichés in question concern the Western

Marina F. Bykova

mfbykova@ncsu.edu

1 Department of Philosophy and Religious Studies, North Carolina State University, Raleigh, NC, USA 
reception of Russian philosophy of the Soviet era. Until now, there persists a view that philosophy in Russia during the entire Soviet period was nothing more than dogma, and it became rather detrimental to Russian cultural and intellectual life. Yet the intellectual life and the real situation in philosophy under the Soviet regime came to be far from homogeneous - and was much more complex than the above view suggests. The Institute's history that largely traces the development of Russian philosophy in the Soviet period had been marked by a variety of ideological and political struggles producing many intellectual milestones that could serve as evidence of the rise and fall of thought. During these trying times, there emerged thinkers who not only successfully maintained the high standards of criticism achieved by pre-revolutionary Russian philosophers, but also produced original and creative ideas that effectively advanced philosophical knowledge.

A retrospective look at the history of the Institute allows us to distinguish four main periods that mirror many struggles endured by Soviet philosophy at large.

In the first period spanning from 1921 to 1929 , philosophy developed mainly as an academic and scholarly pursuit. However, these early years of the Institute's existence were not trouble-free either. If initially the Institute accommodated thinkers who represented a variety of philosophical views, including ones not loyal to Marxism, then in 1922 many of those who did not share Marxist ideas came to be expelled, often both from the Institute and from their country. Among those ousted and forcibly deported from Russia were the religious philosophers Boris P. Vysheslavtsev, Ivan A. Ilyin, and Semyon L. Frank. While Shpet himself escaped this destiny, in 1923 he was removed from the post of Director and had to leave the Institute. After this cleaning-up action, only the adherents of Marxism remained at the Institute. However, until about 1930, philosophizing in a non-Marxist manner and publishing on a variety of topics not immediately relevant to Marxism remained a legitimate business. In spite of the increasing politicization of philosophical debates, philosophy successfully retained its disciplinary focus. Even when the infamous debate between "mechanists" and "dialecticians" came to an impasse and had to be resolved by decree that condemned mechanicism and declared the win of the "dialecticians" headed by Deborin, philosophy—to some extent—still remained resistant to the rising political and ideological tensions, and some genuine activity within the discipline endured, although not for very long.

The second period in the Institute's history that began in 1930 and continued until the early 1950s and that coincided with the ruling of Stalin was perhaps the darkest time in its existence. This came to be the dull period of philosophical dogmatism accompanied by vile suppression of creativity and original thought. Any attempt at a genuine philosophical inquiry had been banished, forbidden, and prosecuted. Transformed into the state ideology, philosophy stopped being free, creative thinking in search of truth. Commissioned by Stalin, the Short Course (1938) that codified the key ideas of Marxism-Leninism as a set of oversimplified principles of dialectical materialism converted philosophy into dogma, depriving it of the right to be independent and politically free. The Communist Party tightened political and ideological control over philosophy, and the top party leaders and Stalin personally declared themselves the highest authority in the field. The Institute suffered from Stalinist repressions of the 1930s and 1940s, losing its best members to mass political terror. 
Newly hired, mostly young red professors ("Ikapists," the graduates of the Institute of Red Professors [Institut krasnoy professury]) who turned out to be party propagandists and not independent-minded scholars quickly transitioned to leadership roles within the Institute and philosophy at large. The production of philosophical research drastically declined. Planned and ongoing research projects, including the one aimed at the preparation of the Encyclopedia of World Philosophy, were discontinued. All genuine philosophy virtually came to a halt, and only after Stalin's death did the situation begin to change.

The Twentieth Congress of the Communist Party of the Soviet Union (CPSU) in February 1956, which declared the course of the de-Stalinization of the country, revitalized intellectual and cultural life in the country, thus shaping conditions for creative philosophical inquiry. The revival of philosophy that became a conceptual core of the third period-spanning almost four decades - in the Institute's history is largely associated with a new generation of philosophers who began to emerge during a decade of relative liberalization ushered in by Khrushchev's "Thaw." There is a widespread view (another misleading cliché) that at the end of the 1950s and early 1960s, Russian philosophical thought was brought to life and remained a living stream thanks exclusively to such "emblematic" figures as Evald V. Ilyenkov, Alexander A. Zinoviev, and Merab K. Mamardashvili, whose professional lives were tidily connected to the RAS Institute of Philosophy. While there is no doubt that these thinkers greatly contributed to the resuscitation of philosophy in Soviet Russia, and as such they occupy a special place in the Russian philosophical movement of the 1960s-1970s, canonizing these figures and presenting Russian philosophy of this period focusing only on them leads to a distorted picture of that time. Perhaps it would be more accurate to see the renewal of philosophy that took place in Soviet Russia in the 1960s-1970s as the achievement of the whole generation of the thinkers known as the Sixtiers (shestideciatniki), a cultural and social phenomenon that still needs an appropriate conceptualization. While the Sixtiers' cohort was not homogeneous, and they worked in different disciplines within philosophy, they all exhibited an enormous thirst for freedom and striving for self-expression, and all of them shared the desire to change the status quo of philosophy. They came out not merely as individual stars but even more so as constellations of thinkers capable of generating new ideas and original philosophical thoughts, thus advancing philosophical knowledge. If we talk about the Institute of Philosophy, at least several other names deserve mention-among them Bonifaty M. Kedrov, Pavel V. Kopnin, Lev N. Mitrokhin, Genrikh S. Batishchev, Vladimir A. Smirnov, Oleg G. Drobnitskii, Ivan T. Frolov, and many, many others who in the 1960s-1970s energized and invigorated Russian philosophy under the Soviet regime. To be sure, the Sixtiers never viewed themselves as anti-Marxists or dissidents. They continued working within the framework of Marxism, while rigorously opposing its orthodox version as uncritical and noncreative. They also argued for humanistic socialism that should be capable of self-criticism and self-correction. However, this progressive trend remained very marginal and insignificant to overturn dogmatic Marxism that preserved its central position through the Khrushchev era. Thus, when the "Thaw" came to an end, the stagnated dogmatism in philosophy became an even bigger obstacle for new philosophical ideas and approaches. The following era restored an authoritarian ideology, 
heightened repressions, and clamped down on freedom of thought; the iron curtain descended again. In that environment, philosophy of the Sixtiers became a kind of underground, acquiring the status of an "unofficial" philosophy. And despite the oppressive social conditions within the country, the Institute of Philosophy continued to shelter and nurture this "unofficial" philosophy, resisting ideological pressure from above and protecting thinkers representing that trend from hostility and prosecution. As one of the key representatives of the philosophical generation of the Sixties, Erich Yu. Soloviev recalls, "even in the most oppressive periods of stagnation not only did the Institute resist the imposition of this atmosphere, but it openly refused to take part in any campaign of condemnation or ideological reprisal against nonconformists, whether in philosophy, literature, economics, or politics. The reigning atmosphere in the Institute at that time was one of glasnost', open argument, and constructive discussion. ... While in the country as a whole there had never been a civil society, the Institute always possessed and actively displayed the key features of such an institution" (Soloviev 2009, p. 83).

The collapse of the Soviet Union and its following dissolution (in 1991) marked the beginning of the current period in the Institute's history that, out of lack of a better term (or perhaps out of convenience), is usually called the post-Soviet era. Philosophy and philosophical life in contemporary Russia evolve in an atmosphere of a free exchange of ideas and views. The landscape of philosophical themes and topics has changed radically, becoming a thing of individual choices and preferences rather than a directive dictated by any kind of authority. Philosophy became truly pluralistic, allowing the pursuit of different interests, the development of a great variety of doctrines, and representation of myriad schools, positions, and movements. The very atmosphere that emerges from the diversity of philosophical discourses and theories is the most important and valuable feature of the Institute of Philosophy. The plurality of ideas and insights greatly contributes to the flourishing of philosophical enterprise, giving rise to new views and concepts. Among those who had been affiliated with the Institute during the first decades of the post-Soviet period are such diverse thinkers as Vladimir V. Bibikhin, Teodor I. Oizerman, Vadim M. Mezhuev, Valery A. Podoroga, Alexander P. Ogurtsov, Vyacheslav S. Stepin, Boris G. Yudin, Sergey S. Horujy, Nelly V. Motroshilova, Piama P. Gaidenko, and many others. I limit my list only to these few names in order to stress the diversity of the positions present within the contemporary Russian philosophical landscape. I also want to pay tribute to the colleagues and friends who recently passed away. These scholars had unique intellectual voices and made exceptional contributions to the philosophical field; all of them worked at the RAS Institute of Philosophy for many years, becoming instrumental to shaping both this institution and Russian philosophy to which they dedicated their lives.

Today, more than 250 researchers work at the Institute, among whom are scholars with world-class reputations, original and creative thinkers at the top of their fields of study. Originally including only a few units with about two dozen staff members, in 100 years the Institute has grown into a large research institution, a one-of-akind in terms of its aims and structure. A leading Russian institution in the humanities and social sciences, it has a worldwide reputation as one of the best centers of advanced and sophisticated research in philosophy. In its present-day form, the 
Institute consists of more than thirty research units working on a variety of themes and topics that together cover nearly all existing areas of philosophical study. The Institute's library possesses an impressive collection of Russian and foreign books, new and old journals, archival documents, and a great variety of reference materials available to those associated with the institution. The production of the Institute's publishing house includes book series, single-author monographs, and collections, as well as philosophical journals and yearbooks. But certainly most important is the creative and productive environment that prevails at the Institute; this is an atmosphere permeated by the spirit of philosophy. In fact, the whole Institute is a kind of laboratory of free philosophical thought.

The Institute affirms its commitment to academic freedom and open inquiry, to free creativity and collegiality, to moral and ethical values, and to its philosophical heritage. It enthusiastically carries the torch handed to it across this century by those who founded this institution. It enters the second century with much vision and optimism, ready to chart the Institute's unbridled future. May the future be bright and successful!

\section{References}

Guseinov, A. A. 2021. Philosophy and society (the 100th anniversary of the RAS Institute of Philosophy (1921-2021)). Herald of the Russian Academy of Sciences 91 (4): 501-513.

Guseinov, A. A., Smirnov, A. V. 2021. Preface. In Institut nauchnoi filosofii. Nachalo [The Institute of Scientific Philosophy. The Beginning], ed. Anatoly V. Chernyaev, Tatiana G. Shchedrina, 11-15. Moscow: IFRAN; Politicheskaia Encyclopediia.

Soloviev, E. 2009. The Institute of Philosophy has long been an institution of civil society. Russian Studies in Philosophy 48 (1): 83-100.

Publisher's Note Springer Nature remains neutral with regard to jurisdictional claims in published maps and institutional affiliations. 